\title{
Tuberculosis - New perspectives on an old disease
}

fter many years, rates of tuberculosis, which have been declining in developed countries and plateauing in developing Acountries, have recently risen significantly. In many regions, this has been on the basis of human immunodeficiency virus (HIV) infection (1). Additional factors have included reduced funding and focus on tuberculosis as a public health problem, and major regional disruptions in the fabric of society, for example, in eastern Europe and sub-Saharan Africa. Global migration patterns are such that increased rates of disease, and, more ominously, drug resistance, will have an impact on tuberculosis control in Canada. Over 50\% of all cases diagnosed in Canada are among the foreign-born; as the Pacific Rim is the predominant region for immigration to Canada, this proportion is likely to rise.

Thus far, HIV-related tuberculosis has not posed a major problem (2) but this may change if HIV infection becomes established in groups with a high prevalence of tuberculosis, for example, in aboriginal Canadians.

Faced with this challenge, the Canadian Lung Association and the Canadian Thoracic Society through its Tuberculosis Committee is providing a critical mass of expertise. Recognizing the need for better education of physicians and health care workers about the management of tuberculosis, the committee created a speakers' bureau with a list of designated speakers across the country. These speakers are available through the provincial lung associations for continuing medical education events. The committee recently published a statement on tuberculosis control to review practical management issues for clinicians (3) and is revising the Canadian Lung Association tuberculosis standards (4).

In an attempt to provide focus for tuberculosis-related research in Canada, Dr Richard Menzies, Chair of the Canadian Lung Association International Committee, recently coordinated a workshop in collaboration with the International Development Research Centre (IDRC) to evaluate the potential contribution of Canadians. The International Committee of the Lung Association has also been involved in developing a bilateral program to assist the Dominican Republic's tuberculosis control program.

Canada has a strong tradition in the area of tuberculosis control dating back to Ferguson in Saskatchewan, who carried out one of the first controlled trials of the use of bacillus Calmette-Guérin (BCG) vaccine, through to the modern era, with physicians such as Dr Don Enarson, Scientific Director of the International Union Against Tuberculosis and Lung Disease, Dr Stefan Grzybowski, Consultant to the World Health Organization's global tuberculosis program, and Dr Earl Hershfield, coeditor of a recently published major new textbook on tuberculosis (5). The Canadian Lung Association and the Canadian Thoracic Society are committed to continuing the strong tradition of advocacy for the support of tuberculosis control programs in Canada and, of equal importance, contributing to the reduction of the global tuberculosis problem.

Individual physicians can play a key role in the control of tuberculosis by supporting these efforts and, in particular, joining the International Union Against Tuberculosis and Lung Disease with its many membership advantages, most notably receiving its excellent journal, Tubercle and Lung Disease. The address for membership application is:

The International Union Against Tuberculosis and Lung Disease,

6800 Boulevard Saint Michel,

75006 Paris, France.

J Mark FitzGerald MB FRCPC

$B C$ Centre for Disease Control

Chair Canadian Thoracic Society's Tuberculosis Committee

\section{REFERENCES}

1. FitzGerald JM, Grzybowski S, Allen EA. The impact of human immunodeficiency virus infection on tuberculosis and its control. Chest 1991;106:191-200.

2. Korzeniewska-Kosela M, FitzGerald JM, Vedal S, et al. Spectrum of tuberculosis in patients with HIV infection in British Columbia: A report of 40 cases. Can Med Assoc J 1992;146:1927-34.

3. FitzGerald JM, Allen EA, Fanning A, et al. Essentials of tuberculosis control for the practising physician. Can Med Assoc J 1994;150:1561-71.

4. Standards Committee (Tuberculosis), Canadian Thoracic Society. Canadian Tuberculosis Standards, 3rd edn. Ottawa: Canadian Lung Association, 1988.

5. Reichman LB, Hershfield ES, eds. Tuberculosis: A Comprehensive International Approach. Lung Biology in Health and Disease. New York: Marcel Dekker, $1993 ; 66$. 


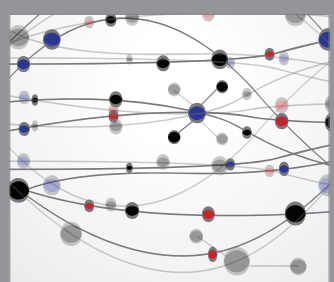

The Scientific World Journal
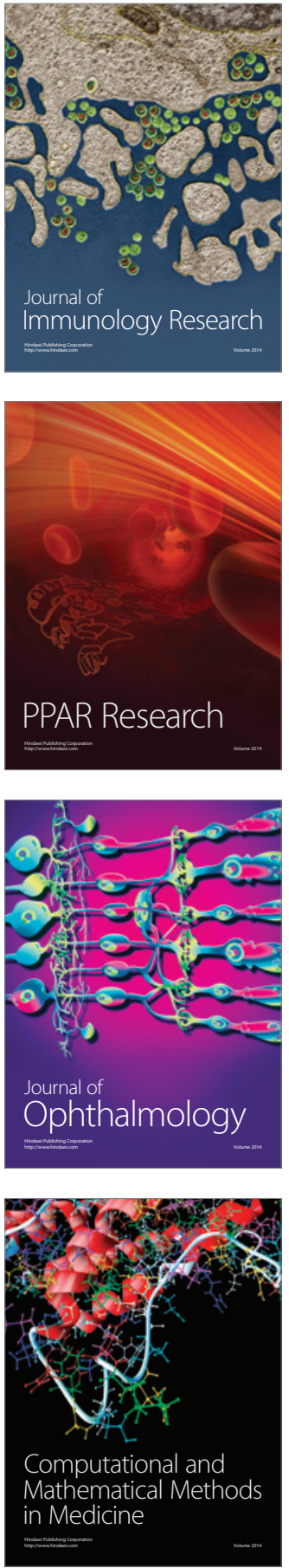

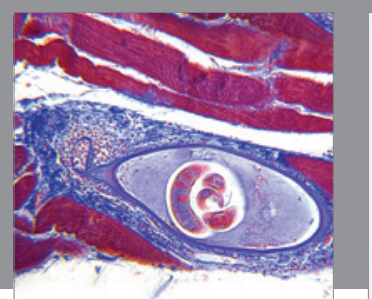

Gastroenterology Research and Practice

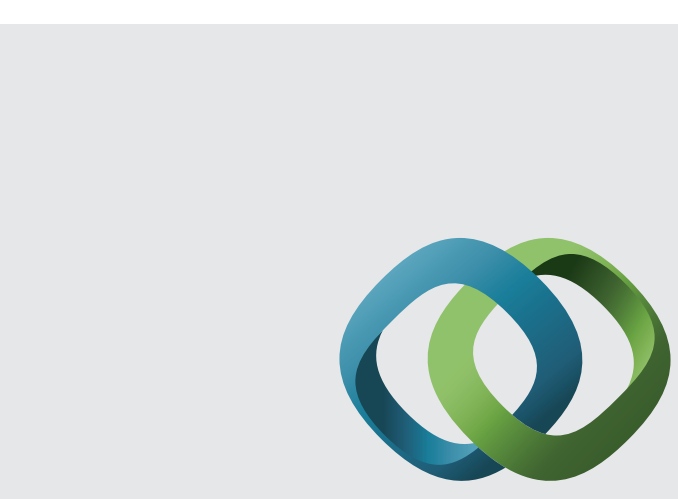

\section{Hindawi}

Submit your manuscripts at

http://www.hindawi.com
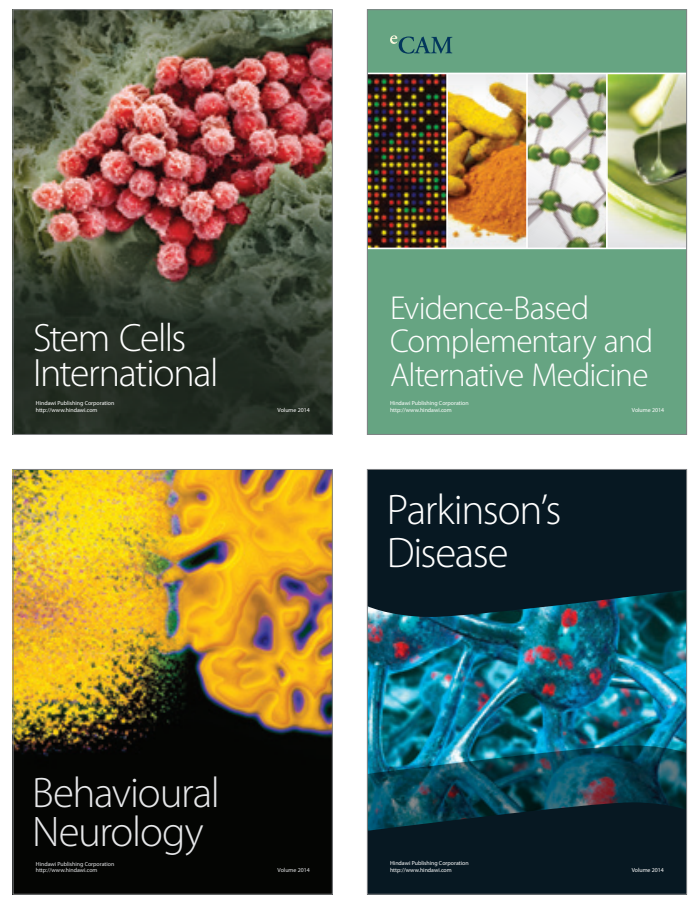
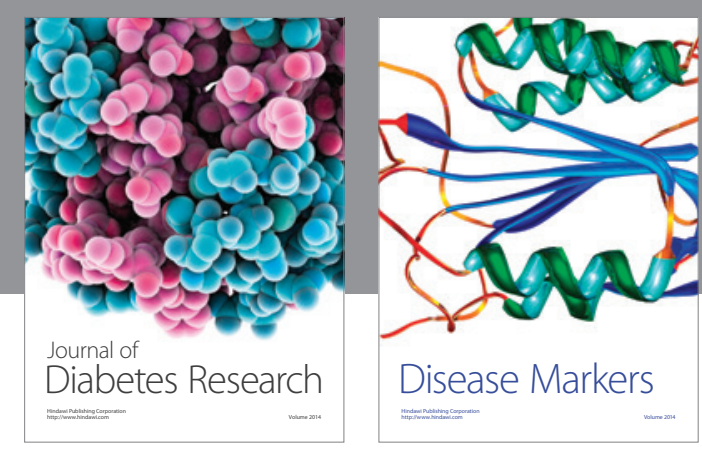

Disease Markers
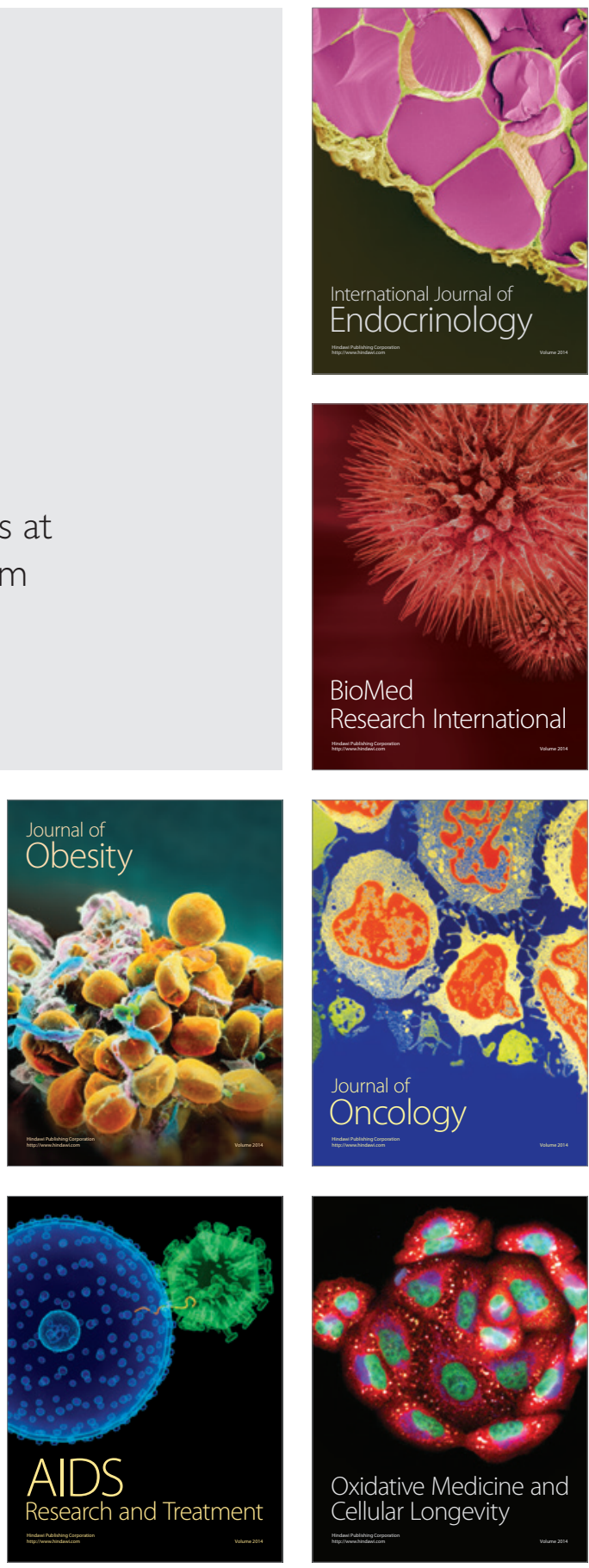